\title{
Fat cells gain new identities
}

Citation for published version (APA):

Nascimento, E. B. M., Boon, M. R., \& van Marken Lichtenbelt, W. D. (2014). Fat cells gain new identities. Science Translational Medicine, 6(247), [247fs229]. https://doi.org/10.1126/scitransImed.3009809

Document status and date:

Published: 30/07/2014

DOI:

10.1126/scitransImed.3009809

Document Version:

Publisher's PDF, also known as Version of record

Document license:
Taverne

\section{Please check the document version of this publication:}

- A submitted manuscript is the version of the article upon submission and before peer-review. There can be important differences between the submitted version and the official published version of record.

People interested in the research are advised to contact the author for the final version of the publication, or visit the DOI to the publisher's website.

- The final author version and the galley proof are versions of the publication after peer review.

- The final published version features the final layout of the paper including the volume, issue and page numbers.

Link to publication

\footnotetext{
General rights rights.

- You may freely distribute the URL identifying the publication in the public portal. please follow below link for the End User Agreement:

www.umlib.nl/taverne-license

Take down policy

If you believe that this document breaches copyright please contact us at:

repository@maastrichtuniversity.nl

providing details and we will investigate your claim.
}

Copyright and moral rights for the publications made accessible in the public portal are retained by the authors and/or other copyright owners and it is a condition of accessing publications that users recognise and abide by the legal requirements associated with these

- Users may download and print one copy of any publication from the public portal for the purpose of private study or research.

- You may not further distribute the material or use it for any profit-making activity or commercial gain

If the publication is distributed under the terms of Article $25 \mathrm{fa}$ of the Dutch Copyright Act, indicated by the "Taverne" license above, 
CELL BIOLOGY

\title{
Fat Cells Gain New Identities
}

\author{
Emmani B. M. Nascimento, ${ }^{1 *}$ Mariëtte R. Boon, ${ }^{1,2 *}$ \\ Wouter D. van Marken Lichtenbelt ${ }^{1} \dagger$
}

ASC-1, PAT2, and P2RX5 are newly identified cell surface proteins that may distinguish brown/beige from white adipocytes in mouse and human adipose tissue (Ussar et al., this issue).

\section{DIFFERENTIATING FAT}

Use it or lose it is the modus operandi of brown adipose tissue (BAT); keep it for later is that of white adipose tissue (WAT). Whereas WAT stores lipids in the form of triglycerides, BAT combusts fatty acids to form heat via uncoupling protein 1 (UCP1), bypassing ATP production. The presence of active BAT in adult humans was proven in 2009 when regions that showed high uptake of radioactively labeled glucose on positron emission tomography-computed tomography (PET-CT) scans histologically resembled BAT (1-3). But what is the physiological relevance of BAT in humans? The notion that obese subjects possess lower amounts of BAT as compared with that of lean subjects suggests a role for BAT in energy expenditure. Indeed, cold acclimation enhances BAT volume and activity and results in reduced fat mass, suggesting that BAT activation is a promising target to combat obesity and associated disorders in humans $(4,5)$.

In mice, BAT depots are well defined and are composed of cells derived from a Myf5positive lineage. Human BAT derived from deep neck adipose tissue genetically resembles mouse BAT, although its mitochondrial respiration is lower, and Myf5 expression has not yet been reported (6). In mice WAT, UCP1-expressing "beige" (or "brite") adipocytes can be detected after prolonged cold exposure or peroxisome proliferatoractivated receptor $\gamma$ (PPAR $\gamma)$ agonism. Upon stimulation, these beige adipocytes acquire a "brownish" (BAT-like) phenotype with multilocular lipid droplets and high UCP1 expression. In humans, recent studies suggest that BAT is composed of a mixture of brown and beige adipocytes (6). Beige

'Department of Human Biology, Maastricht University, P.O. Box 616; 6200MD Maastricht, the Netherlands. 2Department of Endocrinology, Leiden University, P.O. Box 9600; 2300RC Leiden, the Netherlands.

*These authors contributed equally to this work. +Corresponding author. E-mail: markenlichtenbelt@ maastrichtuniversity.nl adipocytes are also detected in human WAT, especially in patients who are chronically exposed to high levels of catecholamines.

But from where do these beige adipocytes in human BAT and (mouse) WAT derive? There is not yet an answer to this question, but possible explanations are from both differentiation of beige precursor cells and transdifferentiation of white adipocytes (7). Thus, beige adipocytes are probably dynamic cell types that can rapidly appear when needed-for instance, when the demand for thermogenesis is high. However, understanding the role of brown and beige adipocytes in substrate utilization and whole-body metabolism is far from complete, especially in humans. Identification of cell-surface markers that are specific to brown, beige, and white adipocytes may provide novel insights into fat cell biology and also facilitate the discovery of new therapeutics that target, for example, BAT. In this issue of Science Translational Medicine, Ussar et al. (8) indeed define three new cell-surface markers that can distinguish the different types of adipocytes and could therefore be used to identify and target these cells in vivo.

\section{CELL-SURFACE MARKERS}

To better understand brown and beige adipocyte biology in mice and in humans, proper identification of the different cell types is essential. By performing in silico, in vitro, and in vivo studies, Ussar et al. sought to identify markers for white, brown, and beige adipocytes. In the in silico studies, adiponectin was used as a model gene for white adipocyte specificity in order to identify previously unknown WAT-specific markers. A similar approach was used for BAT, with the brown adipocyte-specific gene UCP1. Genes that correlated with adiponectin or UCP1 expression had a high expression level in adipose tissue, and encoded cell surface proteins were included in the marker search.
Through this approach, Ussar et al. selected ASC-1 as the surface marker for white adipocytes and the amino acid transporter PAT2 and the purinergic receptor P2RX5 as markers of brown and beige fat cells (Fig. 1). These markers, selected in silico, were then validated in mouse and human adipose tissue. The authors used a broad validation process, including verification of the cell-surface markers through immunofluorescence in adipose tissue cultures, as well as determination of gene and protein expression levels in lean and obese mouse and human adipose tissue. Furthermore, marker expression was determined upon differentiation of various brown and white adipose tissue cultures. The latter method, especially, may provide valuable insights regarding the possible role of these cell-surface markers for adipose tissue biology, although more studies will be needed to elucidate the precise functional role.

\section{ASC-1, PAT2, AND P2RX5 IN ADIPOCYTE BIOLOGY}

With the identification of the cell-surface markers described by Ussar et al. (8), an important question arises regarding the physiological role of these markers in adipocyte biology. ASC-1, PAT2, and P2RX5 were nearly absent in mouse and human preadipocytes but were induced upon adipocyte differentiation, suggesting a role in adipocyte formation and/or physiology. Consistent with this, expression of PAT2 and $P 2 R X 5$ was lower in BAT of diabetic $(d b / d b)$ mice, which is in line with the "whitening" of BAT. Conversely, whereas P2RX5 expression was enhanced in WAT upon cold exposure (also known as "browning" of WAT), ASC-1 was down-regulated.

How could PAT2 and P2RX5 be physiologically linked to activation of brown adipocytes? Because PAT2 and P2RX5 are both membrane transporters (amino acid transporter and ion channel, respectively), they may be linked to intracellular signaling pathways involved in BAT activation. A main activation route of brown adipocytes is the $\beta_{3}$-adrenergic pathway, resulting in increased levels of intracellular cyclic cAMP, activation of protein kinase A, and subsequent phosphorylation of downstream targets. Whether the $\beta_{3}$-adrenergic pathway and/or other intracellular pathways are coupled to PAT2 and P2RX5 membrane transporters remains to be determined-for instance, by the study of intracellular signaling cascades in brown adipocytes in vitro upon 


\begin{tabular}{|c|c|c|c|}
\hline \multirow{6}{*}{ White $\rfloor^{A S C-1}$} & Marker & Adipocyte type & $\begin{array}{c}\text { Plasma membrane? } \\
\text { (YES/NO) }\end{array}$ \\
\hline & Leptin & White & NO \\
\hline & Adiponectin & White & NO \\
\hline & ASC-1 & White & YES \\
\hline & $\mathrm{HOXC8}$ & White & NO \\
\hline & HOXC9 & White & NO \\
\hline \multirow{8}{*}{ Beige } & SP100 & Beige & NO \\
\hline & CD40 & Beige & YES \\
\hline & Ear2 & Beige & NO \\
\hline & CD137 & Beige & YES \\
\hline & UCP1 & Beige/brown & NO \\
\hline & PGC1 $\alpha$ & Beige/brown & NO \\
\hline & PAT2 & Beige/brown & YES \\
\hline & P2RX5 & Beige/brown & YES \\
\hline \multirow{7}{*}{ Brown } & TMEM26 & Beige/brown & YES \\
\hline & PRDM16 & Brown & NO \\
\hline & CIDEA & Brown & NO \\
\hline & Eva1 & Brown & YES \\
\hline & Ebf3 & Brown & NO \\
\hline & Hspb7 & Brown & NO \\
\hline & $\mathrm{ZIC} 1$ & Brown & NO \\
\hline
\end{tabular}

Fig. 1. Distinguishing white, beige, and brown. The table shows a selection of identified markers of different adipocytes. Several markers can be present on both beige and brown adipocytes. A subset of markers is present at the plasma membrane, including ASC-1, P2RX5, and PAT2 (boldface entries). Of these, Ussar et al. suggest that PAT2 is more of a beige cell marker, whereas P2RX5 is more of a brown cell marker (8).

stimulation with ligands for these transporters or evaluation of brown adipocyte function after BAT-specific knockout of PAT2 or P2RX5. This combined approach might yield pharmacological ligands of these transporters capable of stimulating BAT activity in vivo.

\section{CLINICAL IMPLICATIONS}

Enhancing BAT activity could combat type 2 diabetes and obesity. As such, it will be important to determine whole-body distribution of BAT and WAT-for instance, using the cell-surface markers newly identified by Ussar et al. (8). Many research groups have paved the way in the quest to identify white, beige, and brown adipocytes in human adipose tissue on the basis of molecular markers. Several markers for beige/brown adipo-

cytes have been linked to the high number of mitochondria present in these cells (such as PGC1 $\alpha$ and PRDM16) (Fig. 1). The list of additional markers presented to distinguish adipocytes is extensive and includes several genes and microRNAs. Molecular markers identified within various studies-namely, ZIC1, EVA1, CIDEA, TMEM26, CD137, TBX1, FBXO31, and EBF3-are not necessarily specific for classical brown or beige cells. This could be explained by the fact that brown adipose tissue samples can be collected at different locations (for example, the superficial or deep neck region or the supraclavicular region) $(6,9)$. Moreover, some "established" markers can be detected in other nonadipose tissues as well. For example, CD137 is expressed on immune cells and human primary tumors. Importantly, most markers are not expressed at the cell surface, eliminating the possibility for antibody-based purification (Fig. 1). In their study, Ussar et al. have thus handed the scientific community new tools to distinguish white, beige, and brown adipocytes according to surface expression (8). These markers could be used for detecting fat cells, for distinguishing brown from beige adipocytes, or for targeting therapeutics.

The current gold standard for BAT detection in adult humans is the cold-induced ${ }^{18} \mathrm{~F}$-fluorodeoxyglucose (FDG) PET-CT scan, which relies on the visualization and quantification of the glucose analog FDG. Brown adipocytes only take up glucose upon activation (with cold); as such, use of a cooling protocol before conductance of the PET-CT scan is necessary. Imaging methods that rely on constitutively expressed cell surface proteins on differentiated brown adipocytes would allow for quantification of BAT without cold stimulation. This method may be especially useful in assessing the response of BAT volume to pharmacological stimuli because cold exposure before imaging may actually mask the true effect of the intervention.

Considering the specificity of PAT2 and P2RX5 for BAT visualization, a few statements could be made. As compared with PAT2, expression of P2RX5 appeared to be lower in WAT, making it more BAT-specific (Fig. 1). Conversely, P2RX5 was also detected on brown preadipocytes. This could limit the use of this marker to the assessment of BAT volume because brown preadipocytes are evidently also present in BAT, resulting in an overestimation of BAT volume. Brown and beige adipocytes may be distinguished in vivo by means of the cellsurface markers PAT2 and P2RX5; however, Ussar et al. indicate that P2RX5 may be more of a brown adipocyte marker and PAT2 a beige adipocyte marker, making the clear distinction between the two cell types difficult at present. Thus, future studies are needed to assess whether these markers discretely represent the two BAT subtypes, primarily by determining the physiological role of these markers in BAT biology. Furthermore, targeting molecules should be designed to extracellular epitopes of PAT2 and P2RX5 in order to use these extracellular markers for imaging purposes.

Therapeutically, it is tempting to speculate whether drugs targeting markers such as PAT2 and P2RX5 may be used to activate BAT in obese individuals in vivo. An exciting area of current research is the effectiveness of enhancing human BAT activation, resulting in increased energy expenditure and reduced adipose tissue mass accumulation, also taking into account possible differences in ethnic background. For instance, South Asian people have lower BAT volume and activity as compared with those of Caucasians (10). Currently, our understanding of BAT biology and metabolism is vastly increasing, and previously unidentified markers such as PAT2 and P2RX5 will provide new steps toward successful targeting and activating of BAT in humans. Combined with the identification of white adipocytes by using ASC-1, a distinction can be made between white, beige, and brown adipocytes. This may eventually result in generation of a detailed distribution pattern of these adipocyte types and identification of people who may benefit most from a BAT-targeted strategy in order to combat obesity and related disorders, such as type 2 diabetes. 


\section{REFERENCES}

1. W. D. van Marken Lichtenbelt, J. W. Vanhommerig, N. M. Smulders, J. M. Drossaerts, G. J. Kemerink, N. D. Bouvy, P. Schrauwen, G. J. Teule, Cold-activated brown adipose tissue in healthy men. N. Engl. J. Med. 360, 1500-1508 (2009).

2. A. M. Cypess, S. Lehman, G. Williams, I. Tal, D. Rodman, A. B. Goldfine, F. C. Kuo, E. L. Palmer, Y. H. Tseng, A. Doria, G. M. Kolodny, C. R. Kahn, Identification and importance of brown adipose tissue in adult humans. N. Engl. J. Med. 360, 1509-1517 (2009).

3. K. A. Virtanen, M. E. Lidell, J. Orava, M. Heglind, R. Westergren, T. Niemi, M. Taittonen, J. Laine, N. J. Savisto, S. Enerbäck, P. Nuutila, Functional brown adipose tissue in healthy adults. N. Engl. J. Med. 360, 1518-1525 (2009).

4. A. A. van der Lans, J. Hoeks, B. Brans, G. H. Vijgen, M. G. Visser, M. J. Vosselman, J. Hansen, J. A. Jörgensen, J. Wu F. M. Mottaghy, P. Schrauwen, W. D. van Marken Lichtenbelt, Cold acclimation recruits human brown fat and increases nonshivering thermogenesis. J. Clin. Invest. 123, 3395-3403 (2013).
5. T. Yoneshiro, S. Aita, M. Matsushita, T. Kayahara, T. Kameya, Y. Kawai, T. Iwanaga, M. Saito, Recruited brown adipose tissue as an antiobesity agent in humans. J. Clin. Invest. 123, 3404-3408 (2013).

6. A. M. Cypess, A. P. White, C. Vernochet, T. J. Schulz, R. Xue, C. A. Sass, T. L. Huang, C. Roberts-Toler, L. S. Weiner, C. Sze, A. T. Chacko, L. N. Deschamps, L. M. Herder, N. Truchan, A. L. Glasgow, A. R. Holman, A. Gavrila, P. O. Hasselgren, M. A. Mori, M. Molla, Y. H. Tseng, Anatomical localization, gene expression profiling and functional characterization of adult human neck brown fat. Nat. Med. 19, 635639 (2013).

7. M. Rosenwald, A. Perdikari, T. Rülicke, C. Wolfrum, Bidirectional interconversion of brite and white adipocytes. Nat. Cell Biol. 15, 659-667 (2013).

8. S. Ussar, K. Y. Lee, S. N. Dankel, J. Boucher, M.-F. Haering, A. Kleinridders, T. Thomou, R. Xue, Y. Macotela, A. M. Cypess, Y.-H. Tseng, G. Mellgren, C. R. Kahn, ASC-1, PAT2, and P2RX5 are cell surface markers for white, beige, and brown adipocytes. Sci. Transl. Med. 6, 247ra103 (2014).
9. J. Wu, P. Boström, L. M. Sparks, L. Ye, J. H. Choi, A. H. Giang M. Khandekar, K. A. Virtanen, P. Nuutila, G. Schaart, K. Huang, H. Tu, W. D. van Marken Lichtenbelt, J. Hoeks, S. Enerbäck, P. Schrauwen, B. M. Spiegelman, Beige adipocytes are a distinct type of thermogenic fat cell in mouse and human. Cell 150, 366-376 (2012).

10. L. E. Bakker, M. R. Boon, R. A. van der Linden, L. P. AriasBouda, J. B. van Klinken, F. Smit, H. J. Verberne, J. W. Jukema, J. T. Tamsma, L. M. Havekes, W. D. van Marken Lichtenbelt, I. M. Jazet, P. C. Rensen, Brown adipose tissue volume in healthy lean south Asian adults compared with white Caucasians: A prospective, case-controlled observational study. Lancet Diabetes Endocrinol 2, 210217 (2014).

10.1126/scitranslmed.3009809

Citation: E. B. M. Nascimento, M. R. Boon, W. D. van Marken Lichtenbelt, Fat cells gain new identities. Sci. Transl. Med. 6 247fs29 (2014). 


\section{Science Translational Medicine}

\section{Fat Cells Gain New Identities}

Emmani B. M. Nascimento, Mariëtte R. Boon and Wouter D. van Marken Lichtenbelt

Sci Transl Med 6, 247fs29247fs29.

DOI: 10.1126/scitranslmed.3009809

ARTICLE TOOLS

http://stm.sciencemag.org/content/6/247/247fs29

RELATED

CONTENT

http://stm.sciencemag.org/content/scitransmed/2/20/20ps7.full

http://stm.sciencemag.org/content/scitransmed/3/108/108ra112.full

http://stm.sciencemag.org/content/scitransmed/8/334/334ra54.full

http://stm.sciencemag.org/content/scitransmed/8/335/335ra58.full

REFERENCES

This article cites 10 articles, 1 of which you can access for free http://stm.sciencemag.org/content/6/247/247fs29\#BIBL

PERMISSIONS

http://www.sciencemag.org/help/reprints-and-permissions

Use of this article is subject to the Terms of Service

Science Translational Medicine (ISSN 1946-6242) is published by the American Association for the Advancement of Science, 1200 New York Avenue NW, Washington, DC 20005. The title Science Translational Medicine is a registered trademark of AAAS.

Copyright $@$ 2014, American Association for the Advancement of Science 